\title{
EFEKTIVITAS LAYANAN HAK TANGGUNGAN TERINTEGRASI SECARA ELEKTRONIK DI KANTOR PERTANAHAN KABUPATEN KLATEN
}

\author{
Damar Sagari ${ }^{1}$, Mujiati $^{2}$ \\ ${ }^{1}$ Kantor Wilayah Badan Pertanahan Nasional Provinsi Maluku Utara, Indonesia \\ 2,Sekolah Tinggi Pertanahan Nasional, Yogyakarta, Indonesia \\ Koresponden email: bantulmujiati75@gmail.com
}

Naskah diterima: 15 Januari 2022; revisi: 9 Februari 2022; disetujui: 14 Februari 2022

\begin{abstract}
Today, government agencies are required to modernize services in order to complete work quickly, precisely, and effectively. The Ministry of ATR/BPN realizes these demands through an electronically integrated Mortgage Service (HT-el) which must be implemented by all Land Offices starting June 8, 2020. Based on this, the Klaten Regency Land Office has organized HT-el services since January 2020 to make it easier for partners Ministry of ATR/BPN in obtaining services online. This study uses a qualitative method with a descriptive approach, to describe the effectiveness of HT-el services at the Land Office of Klaten Regency. The purpose of this study was to determine the effectiveness of the implementation of HT-el services as well as the supporting and inhibiting factors of HT-el services at the Land Office of Klaten Regency. This is intended so that problems that are indicated to reduce service quality and community satisfaction can be improved. The results showed that the effectiveness of HT-el services at the Land Office of Klaten Regency received a good response. The effectiveness of these services is inseparable from the supporting and inhibiting factors that affect their implementation.
\end{abstract}

Keywords: effectiveness, Mortgage, Electronic, HT-el

\begin{abstract}
Abstrak: Modernisasi pelayanan pertanahan merupakan keniscayaan agar dapat menyelesaikan pekerjaan secara cepat, tepat, dan efektif. Kementerian ATR/BPN mewujudkan tuntutan tersebut salah satunya melalui pelayanan Hak Tanggungan terintegrasi secara elektronik (HT-el) yang wajib diterapkan oleh seluruh Kantor Pertanahan mulai tanggal 8 Juni 2020. Berdasarkan hal tersebut Kantor Pertanahan Kabupaten Klaten menyelenggarakan layanan HT-el sejak Januari 2020 untuk mempermudah mitra Kementerian ATR/BPN dalam memperoleh pelayanan secara online. Tujuan penelitian untuk mengetahui efektivitas pelaksanaan Layanan HT-el serta faktor pendukung dan penghambat Layanan HT-el di Kantor Pertanahan Kabupaten Klaten. Metode kualitatif untuk menguraikan efektivitas layanan HT-el di Kantor Pertanahan Kabupaten Klaten. Hal itu dimaksudkan agar permasalahan yang terindikasi dapat menurunkan kualitas pelayanan dan kepuasan masyarakat dapat diperbaiki. Hasil penelitian menunjukkan bahwa efektivitas layanan HT-el di Kantor Pertanahan Kabupaten Klaten memperoleh respons yang baik. Efektivitas layanan tersebut tidak terlepas dari faktor pendukung dan penghambat yang mempengaruhi pelaksanaannya.
\end{abstract}

Kata Kunci: efektivitas, Hak Tanggungan, Elektronik, HT-el 


\section{A. Pendahuluan}

Pelayanan tidak dapat dipisahkan dari masyarakat sebagai penerima layanan publik yang berkualitas dari pemerintah. Kualitas pelayanan merupakan perbandingan antara kenyataan atas pelayanan yang diterima dengan harapan atas pelayanan yang ingin diterima. Seiring dengan pertumbuhan ekonomi masyarakat, pemerintah dituntut memaksimalkan pelayanan publik yang efektif, efisien, berkeadilan, transparan, dan akuntabel. Penerapan fungsi pemerintahan yang baik harus mampu bekerja secara profesional, aspiratif, dan mempunyai daya tanggap tinggi terhadap tuntutan masyarakat yang dilayani sehingga merasa puas. Tolak ukur kepuasan suatu kualitas pelayanan bukan hanya dari pihak yang melayani namun juga dari pihak yang menikmati layanan. Kepuasan masyarakat merupakan faktor penentu kualitas suatu layanan. Hal ini berarti untuk menciptakan kepuasan masyarakat terhadap pelayanan publik maka pemerintah perlu meningkatkan kualitas layanan menjadi lebih baik, maju, dan modern sehingga dapat mencerminkan pelayanan prima.

Pelayanan publik pada dasarnya ditujukan untuk melayani masyarakat tanpa mempersulit administrasi dan birokrasi. Jumlah layanan di Kantor Pertanahan tergolong banyak, yaitu pelayanan pendaftaran tanah pertama kali, pelayanan pemeliharaan data pendaftaran tanah, pelayanan pencatatan dan informasi pertanahan, pelayanan pengukuran bidang tanah, pelayanan pengaturan dan penataan pertanahan. Masingmasing layanan tersebut memiliki persyaratan dan prosedur yang berbeda. Pelayanan yang diselenggarakan oleh Kantor Pertanahan sering mendapatkan kesan negatif dari penerima layanan, seperti pada proses pengurusan sertipikat tanah dan pemeliharaan data pertanahan karena pembebanan hak/Hak Tanggungan (HT). Pengurusan sertipikat tanah dinilai rumit dan berbelit-belit, mahalnya biaya yang diperlukan serta terdapat oknum yang mencari keuntungan. Proses HT yang dilaksanakan secara manual yang kemudian disebut HT Konvensional dirasa lama akibat berkas permohonan yang hilang atau terselip sehingga terkesan mempersulit masyarakat karena harus mengulang proses permohonan mulai dari awal.

Kementerian ATR/BPN menyusun langkah strategis yang tertuang pada rencana strategis tahun 2020-2024 agar Kantor Pertanahan dapat bekerja secara terarah dan jelas, sehingga dapat mengatasi keluhan dari penerima layanan pertanahan. Langkah strategis tersebut dilaksanakan melalui program modernisasi layanan pertanahan, salah satunya adalah Layanan Hak Tanggungan Terintegrasi Secara Elektronik (HT-el). Salah satu manfaat layanan HT-el yaitu pengurusan sertipikat Hak Tanggungan dapat dilaksanakan lebih cepat dan praktis dibandingkan pengurusan Hak Tanggungan Konvensional. 
Kementerian ATR/BPN juga bertugas secara maksimal menjamin pelaksanaan kebijakan HT-el telah sesuai standar prosedur yang diatur dalam Peraturan Menteri (Permen) ATR/BPN Nomor 5 Tahun 2020 tentang Pelayanan Hak Tanggungan Terintegritas Secara Elektronik. Berdasarkan peraturan tersebut, kemudian diterbitkan Petunjuk Teknis Nomor 2/Juknis-400.HR.02/IV/2020. Pelayanan Hak Tanggungan Secara Elektronik mulai tanggal 8 Juni 2020 wajib diterapkan oleh seluruh Kantor Pertanahan di wilayah Republik Indonesia dengan mengubah layanan pertanahan berbasis manual menjadi pelayanan berbasis digital.

Kementerian ATR/BPN terus berupaya untuk mewujudkan modernisasi pelayanan masyarakat di seluruh Kantor Pertanahan. Sejak bulan Januari 2020 Kantor Pertanahan Kabupaten Klaten telah melaksanakan pelayanan HT-el untuk mempermudah mitra Kementerian ATR/BPN (PPAT dan Kreditur) dalam memperoleh pelayanan tanpa tatap muka/online. Terlepas dari keunggulan layanan HT-el, sistem ini masih belum memberikan hasil yang maksimal, karena para pengguna sangat bergantung pada tersedianya jaringan internet yang stabil. Selain itu, Kantor Pertanahan Kabupaten Klaten menerbitkan sertipikat HT tanpa melalui proses pemeriksaan oleh petugas. Kejadian tersebut merupakan akibat dari human error karena kurang cermatnya petugas dalam pelayanan. Ada pula berkas yang ditutup karena terdapat unggahan dokumen yang sulit terbaca namun pengguna layanan lamban dalam merespons untuk melakukan perbaikan. Hal tersebut tentu menjadi hambatan untuk mewujudkan keberhasilan pelaksanaan pelayanan HT-el di Kantor Pertanahan Kabupaten Klaten. Kesiapan dan dukungan dari berbagai pihak juga sangat dibutuhkan untuk mendukung keberhasilan pelaksanaan pelayanan HTel sehingga dapat memperbaiki citra layanan Kementerian ATR/BPN dan menciptakan kepuasan penerima layanan.

Pelaksanaan pelayanan HT-el membutuhkan kerja sama dan dukungan dari mitra yang terkait dengan Kementerian ATR/BPN. Bentuk kerja sama diwujudkan dengan menyediakan sistem layanan berbasis online yang dapat diakses oleh pengguna Layanan HT-el (PPAT dan Kreditur) (Gunarta at al, 2020). Hal ini dimaksudkan agar dalam proses layanan tidak diperlukan interaksi secara langsung/tatap muka. Menurut Gunarta at al (2020) layanan HT-el di Kantor Pertanahan Kabupaten Badung telah dilaksanakan sepenuhnya secara online, tetapi pada pelaksanaannya mengalami beberapa kesalahan, seperti terbitnya Sertipikat HT-el tanpa melalui proses pemeriksaan dan terdapat berkas yang ditutup secara otomatis oleh sistem akibat lambatnya respons pengguna layanan.

Beberapa hasil penelitian mengenai HT-el telah dilakukan oleh peneliti sebelumnya diantaranya; pertama, terkait aspek yuridis HT-el yang disharmoni dengan UU Hak 
Tanggungan (Wiguna, 2020; Baswindro, 2020; Amalia at al, 2020). Penelitian ini mengupas tentang prosedur pelaksanaan pelayanan HT-el yang belum sesuai dengan Juknis seperti berkas yang ditangguhkan dan ditutup serta penerbitan sertipikat HT-el tanpa diperiksa oleh Kantor Pertanahan. Penelitian implementasi HT-el di kantor pertanahan (Andiyanto at al, 2021; Exaudia at al, 2021; Nadira, 2019) berkaitan dengan sistem HT-el itu sendiri yang masih perlu penyempurnaan agar semua pelayanan yang terkait dengan hak tanggungan melalui layanan elektronik tersebut. Sedangkan ini adalah melengkapi penelitianpenelitian terdahulu, karena masing-masing kantor pertanahan memiliki kompleksitas permasalahan tersendiri dalam menjalankan HT-el

\section{B. Metode Penelitian}

Metode kualitatif sebagai prosedur penelitian yang menghasilkan data deskriptif dalam bentuk tulisan atau lisan yang dapat diamati (Moleong 2010, 4), yang dideskripsikan secara tepat mengenai bentuk, cara, proses yang sesuai dengan kondisi senyatanya di lapangan (Mardalis, 2013). Data diperoleh melalui wawancara, baik secara langsung maupun melalui whatsapp kepada pengguna layanan HT-el seperti Kreditor dan PPAT yang memiliki permohonan terbanyak di Kantor Pertanahan Kabupaten Klaten, verifikator HTel, Kepala Seksi Hubungan. Selain data hasil wawancara juga diperoleh melalui observasi, dan dokumentasi. Data yang diperoleh kemudian dianalisis dengan teknik analisis deskriptif untuk menjelaskan tentang layanan HT-el, efektivitas layanan HT-el serta faktor pendukung dan penghambat layanan HT-el di Kantor Pertanahan Kabupaten Klaten.

\section{Pelaksanaan Layanan HT-el di Kantor Pertanahan Kabupaten Klaten}

Layanan HT-el di Kantor Pertanahan Kabupaten Klaten dimaksudkan untuk meningkatkan pelayanan hak tanggungan dan untuk memenuhi kebutuhan masyarakat dengan memanfaatkan perkembangan teknologi. Pelaksanaan layanan ini dapat dilihat dari perbandingannya dengan hak tanggungan konvensional, efektivitas layanan, dan faktor-faktor yang mempengaruhi pelaksanaan layanan HT-el di Kantor Pertanahan Kabupaten Klaten.

1. Perbandingan Pelaksanaan Hak Tanggungan Konvensional dan Elektronik

Hak Tanggungan diatur pada Undang-Undang Nomor 4 Tahun 1996 tentang Hak Tanggungan atas Tanah Beserta Benda-Benda yang Berkaitan dengan Tanah, namun tidak terdapat peraturan pelaksanaan ataupun petunjuk teknis. Tuntutan masyarakat kepada Pemerintah untuk tetap meningkatkan kualitas layanan menjadi suatu tantangan, khususnya pada Kementerian ATR/BPN. Langkah awal Kementerian ATR/BPN untuk memenuhi tuntutan tersebut adalah dengan menerbitkan Layanan HT-el yang tertuang 
dalam Peraturan Menteri ATR/BPN Nomor 9 Tahun 2019 tentang Pelayanan Hak Tanggungan Terintegrasi Secara Elektronik. Peraturan tersebut kemudian dicabut dan diganti menjadi Peraturan Menteri ATR/BPN Nomor 5 Tahun 2020 tentang Pelayanan Hak Tanggungan Terintegrasi Secara Elektronik karena dianggap belum mampu memenuhi kebutuhan terkait pelaksanaannya. Berdasarkan peraturan tersebut, diterbitkan Petunjuk Teknis Nomor 2/Juknis-400.HR.02/IV/2020 sebagai pedoman dan standarisasi dalam pelaksanaan pelayanan HT-el. Perbedaan Hak Tanggungan Konvensional dengan Hak Tanggungan Elektronik, sebagai berikut.

Tabel 1. Perbandingan Pelaksanaan Hak Tanggungan Secara Konvensional dan Elektronik

\begin{tabular}{|c|c|c|c|}
\hline No. & Perbedaan & HT Konvensional & HT Elektronik (HT-el) \\
\hline 1. & $\begin{array}{l}\text { Peraturan } \\
\text { Pelaksana }\end{array}$ & UU No. 4 Tahun 1996 & $\begin{array}{ll}\text { - } & \text { Peraturan Menteri ATR/ BPN No. } 5 \\
& \text { Tahun } 2020 \\
\text { - } & \text { Petunjuk Teknis No. } 2 \text { Tahun } 2020\end{array}$ \\
\hline 2. & Pendaftaran & $\begin{array}{l}\text { - Dilaksanakan oleh PPAT } \\
\text { melalui Kantor Pertanahan } \\
\text { - Dilaksanakan pada hari kerja } \\
\text { - Dokumen permohonan asli } \\
\text { dan fotokopi yang } \\
\text { diserahkan ke Kantor } \\
\text { Pertanahan }\end{array}$ & $\begin{array}{l}\text { - Dilaksanakan oleh Kreditur dan } \\
\text { PPAT melalui sistem HT-el } \\
\text { - Dilaksanakan sesuai hari kalender } \\
\text { (hari kerja maupun hari libur) } \\
\text { - Dokumen permohonan softcopy yang } \\
\text { telah di scan dan diunggah pada } \\
\text { Sistem HT-el }\end{array}$ \\
\hline 3. & $\begin{array}{l}\text { Lembar } \\
\text { kedua APHT }\end{array}$ & $\begin{array}{lll}\text { Serahkan } & \text { ke } & \text { Kantor } \\
\text { Pertanahan } & & \end{array}$ & $\begin{array}{l}\text { Upload oleh PPAT pada aplikasi mitra } \\
\text { kerja }\end{array}$ \\
\hline 4. & $\begin{array}{l}\text { Sertipikat } \\
\text { Hak } \\
\text { Tanggungan }\end{array}$ & $\begin{array}{l}\text { - Terbit lebih dari } 7 \text { (tujuh) hari } \\
\text { - Berupa blanko sertipikat } \\
\text { seperti sertipikat Hak Atas } \\
\text { Tanah lainnya }\end{array}$ & 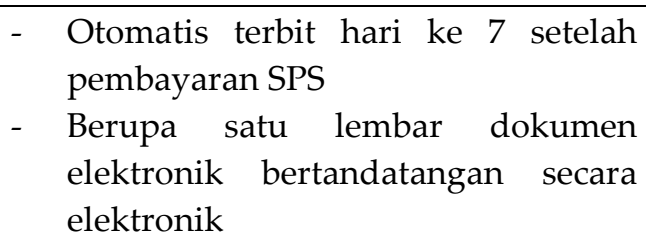 \\
\hline 5. & $\begin{array}{l}\text { Pencatatan } \\
\text { buku tanah } \\
\text { dan sertipikat }\end{array}$ & $\begin{array}{l}\text { - Pencatatan tanggal apabila } \\
\text { jatuh pada hari libur diganti } \\
\text { menjadi tanggal hari kerja } \\
\text { - Dilaksanakan oleh Kantor } \\
\text { Pertanahan kemudian } \\
\text { sertipikat dikembalikan lagi } \\
\text { ke Kreditur } \\
\text { - Tanda tangan dilaksanakan } \\
\text { secara manual }\end{array}$ & $\begin{array}{l}\text { - Pencatatan tanggal sesuai hari ke } 7 \\
\text { menurut kalender meskipun jatuh } \\
\text { pada hari libur } \\
\text { - Catatan pada sertipikat dicetak } \\
\text { menggunakan sticker dan ditempel } \\
\text { oleh Kreditur kemudian catatan pada } \\
\text { buku tanah dicetak menggunakan } \\
\text { sticker dan ditempel oleh petugas } \\
\text { Kantor Pertanahan } \\
\text { - Tanda tangan dilaksanakan secara } \\
\text { elektronik }\end{array}$ \\
\hline 6. & Warkah & $\begin{array}{l}\text { Dokumen disimpan dalam } \\
\text { bentuk hardcopy di Kantor } \\
\text { Pertanahan sehingga } \\
\text { membutuhkan ruangan } \\
\text { untuk menyimpannya. }\end{array}$ & $\begin{array}{l}\text { Dokumen disimpan dalam bentuk } \\
\text { softcopy di sistem pada Aplikasi } \\
\text { sehingga tidak membutuhkan ruangan } \\
\text { untuk menyimpannya. }\end{array}$ \\
\hline
\end{tabular}

Sumber: Hasil Wawancara dan Observasi Peneliti, 2021 
Berdasarkan hasil wawancara mengenai perbandingan antara pelaksanaan Layanan HT Konvensional dan Layanan HT-el menunjukkan bahwa Layanan HT-el lebih efektif dibanding layanan HT Konvensional. Pelaksanaan Layanan HT-el berpedoman pada Petunjuk Teknis 2 Tahun 2020, proses pendaftaran sampai penyerahan produk yang dilaksanakan secara online sehingga lebih praktis karena pemohon tidak perlu antri datang ke Kantor Pertanahan untuk mendaftarkan permohonan dan mendukung pencegahan penyebaran virus COVID-19. Selain itu, waktu pelaksanaan Layanan HT-el menjadi lebih baku karena diatur oleh sistem. Pencatatan dan tanda tangan dilaksanakan secara elektronik melalui sistem kemudian ditempelkan pada Buku Tanah dan Sertipikat. Dokumen permohonan HT-el disimpan oleh sistem sehingga tidak memerlukan ruangan untuk penyimpanannya dan mempermudah dalam proses pencarian dokumen.

2. Efektivitas Layanan HT-el di Kantor Pertanahan Kabupaten Klaten

Kantor Pertanahan mempunyai jumlah permohonan Layanan HT-el rata-rata $70 \mathrm{~s} / \mathrm{d}$ 100 berkas permohonan per hari dengan Sumber Daya Manusia (SDM) sejumlah 4 (empat) orang. SDM tersebut tidak hanya bertugas sebagai pelaksana Layanan HT-el tetapi juga melaksanakan beban kerja lainnya. Layanan HT-el yang dituntut dari segi waktu tentunya sangat mengutamakan kecermatan dan ketelitian. Oleh karena itu, perlu diketahui kualitas Layanan HT-el agar dapat diketahui keefektivitasan Layanan HT-el. Menurut Suit (1996, 94) pengertian efektivitas adalah tindakan yang tepat atau kesempurnaan (jaminan) hasil suatu pekerjaan. Efektivitas merupakan gambaran terkait keberhasilan organisasi dalam mencapai tujuan (target) atau pengukur keberhasilan dalam mencapai tujuan sesuai ketentuan.

Keefektivitasan Layanan HT-el dapat diketahui melalui rangkuman hasil wawancara dengan menggunakan parameter 5 dimensi berdasarkan indikator kualitas pelayanan publik, sebagai berikut.

\section{a. Tangibles (wujud)}

Parameter ini berkaitan tentang tersedianya keperluan pelanggan yang mengutamakan pada fasilitas fisik karena pengguna layanan tetap datang ke Kantor Pertanahan apabila mengalami kendala yang harus diselesaikan secara tatap muka. Indikator dalam parameter ini berupa: Pertama, penampilan petugas dalam melaksanakan pekerjaan. Pelayanan HT-el memang dilaksanakan secara online, meski demikian petugas tetap berpenampilan rapi dan sopan sesuai dengan ketentuan kantor. Kedua, kenyamanan tempat dalam proses pelayanan. Kualitas 
layanan dapat dinilai dari pengguna layanan yang merasa nyaman dengan tempat yang disediakan, ketika harus datang ke Kantor Pertanahan, meskipun pelayanan dilaksanakan secara online.

Ketiga, kelengkapan fasilitas kantor, Indikator ini berkaitan dengan tersedianya fasilitas yang lengkap dan memadai untuk memenuhi kebutuhan petugas dan pengguna layanan sehingga kualitas layanan tergolong memuaskan. Keempat, kemudahan dalam mengakses. Pengguna Layanan mudah mengerti dan memahami pedoman Layanan HT-el yang ada pada buku pedoman maupun petunjuk yang ada di website Kementerian ATR/BPN. Kepuasan pengguna layanan tampak pada kemudahan yang dirasakan oleh PPAT dan Kreditur karena tidak perlu datang ke Kantor untuk mendaftarkan permohonan dan melakukan pencatatan HT pada sertipikat. Alur dan monitoring permohonan HT-el juga dapat dilihat pada sistem sehingga pengguna layanan merasa puas dengan kemudahan dalam mengakses informasi melalui sistem yang tersedia.

b. Reliability (kehandalan)

Parameter ini berkaitan dengan kemampuan dalam melaksanakan pelayanan dengan jelas, handal, dan akurat. Kualitas layanan HT-el dapat dilihat dari respon baik Pengguna Layanan (PPAT dan Kreditur) terhadap indikator berikut:

1) Standar pelayanan yang jelas, seperti Petugas melaksanakan tugas sesuai Standar Operasional Pelayanan (SOP) yang telah ditetapkan sesuai peraturan terkait Layanan HT-el.

2) Kecermatan petugas dalam melaksanakan pelayanan: Pengguna Layanan (PPAT dan Kreditur) selama menggunakan Layanan HT-el pernah mengalami beberapa kesalahan, seperti kesalahan peringkat karena sertipikat yang diunggah belum memiliki catatan terbaru atau catatan pada sertipikat tidak sesuai dengan catatan yang ada di Aplikasi Komputerisasi Kantor Pertanahan (KKP). Selain itu, terjadi berkas terbit tanpa periksa akibat Human Error. Permasalahan tersebut dapat diatasi dengan mengoreksi ulang secara manual antara dokumen fisik dengan dokumen yang tertera di sistem.

3) Kedisiplinan petugas dalam melayani: Jumlah permohonan HT-el yang terbilang banyak menjadikan petugas bekerja secara disiplin waktu. Apabila pekerjaan tidak dapat diselesaikan pada jam kerja petugas melanjutkan pekerjaan (lembur) agar dapat mengoptimalkan kualitas layanan. 
4) Keahlian petugas menggunakan alat: Kantor Pertanahan mempunyai SDM yang kompeten terhadap teknologi, sebagai petugas layanan HT-el, sehingga proses pelayanan dilaksanakan dengan lancar.

c. Responsiviness (kecepatan menanggapi)

Parameter ini berkaitan dengan kesediaan petugas membantu Pengguna Layanan dengan cepat dan tepat. Indikator dalam parameter ini, antara lain:

1) Respon petugas terhadap pengguna layanan: Petugas memberikan respon yang berbeda-beda apabila Pengguna Layanan (PPAT dan Kreditur) mengalami kendala. Respon dari petugas ada yang terbilang menguasai atau sudah berkompeten dan ada juga yang kurang kompeten karena respon yang diberikan terkesan berbelit-belit. Hal ini dapat diselesaikan dengan Pengguna Layanan mendatangi langsung petugas (admin) yang dapat memberikan solusi terhadap kendala yang dialami.

2) Petugas merespon dengan tepat sesuai dengan ketentuan apabila Pengguna Layanan (PPAT dan Kreditur) mengalami kendala dan kesalahan pada dokumen yang diunggah.

3) Petugas melakukan pelayanan dengan waktu yang tepat: Waktu penyelesaian permohonan HT-el dinilai cepat dan tepat meskipun ada beberapa berkas yang terbit tanpa melalui proses pemeriksaan akibat kelalaian petugas. Ketepatan waktu pelayanan seharusnya diimbangi oleh ketelitian yang maksimal.

d. Assurance (jaminan)

Parameter ini berkaitan dengan kesediaan petugas memberikan rasa percaya terhadap layanan yang diberikan. Respons Pengguna Layanan (PPAT dan Kreditur) terhadap parameter ini, yaitu:

1) Jaminan tepat waktu dalam pelayanan: Pengguna Layanan (PPAT dan Kreditur) memberikan respons yang baik terhadap ketepatan waktu pelayanan, karena selama berkas tidak ditangguhkan atau perlu dilakukan perbaikan maka dalam waktu 7 (tujuh) hari Sertipikat HT-el akan terbit.

2) Jaminan kepastian biaya dalam pelayanan: Pengguna Layanan (PPAT dan Kreditur) juga memberikan respons yang baik terhadap biaya pelayanan, karena biaya yang dikeluarkan adalah biaya Pendapatan Negara Bukan Pajak (PNBP) sesuai yang tertera pada Surat Perintah Setor (SPS).

3) Jaminan kepercayaan terhadap kualitas produk: Pengguna Layanan (PPAT dan Kreditur) percaya kualitas produk yang dihasilkan karena produk yang 
diterbitkan merupakan dokumen yang dilengkapi oleh Tanda Tangan Elektronik (TTE) disertai barcode.

e. Emphaty (kesediaan memahami)

Parameter ini berkaitan dengan kesediaan petugas memberikan pelayanan secara profesional. Kualitas layanan tampak pada kepuasan Pengguna Layanan (PPAT dan Kreditur) terhadap indikator berikut:

1) Petugas melayani dengan ramah dan sopan santun: Layanan HT-el merupakan layanan online dan baru tentunya Pengguna Layanan (PPAT dan Kreditur) mengalami berbagai kendala, sikap petugas dalam menanggapi kendala dinilai sangat ramah dan sopan.

2) Petugas melayani dan menghargai pengguna layanan: Petugas melakukan pekerjaan dengan tidak membeda-bedakan pengguna layanan.

3) Petugas mendahulukan kepentingan pengguna layanan dan tidak diskriminasi: Sistem layanan HT-el secara otomatis menampilkan daftar berkas permohonan yang masuk sesuai waktu sehingga petugas memeriksa berkas berurutan sebagaimana mestinya.

3. Faktor Pendukung dan Penghambat Pelaksanaan Layanan HT-el

Pelaksanaan layanan HT-el tidak terlepas dari kekurangan dan kelebihan. Hal tersebut dikarenakan adanya faktor pendukung dan penghambat yang mempengaruhi pelaksanaan layanan HT-el di Kantor Pertanahan Kabupaten Klaten.

a. Faktor Pendukung

1) Peningkatan Kualitas Data Pertanahan

Pengertian kualitas data menurut Petunjuk Teknis Pendaftaran Tanah Sistematis Lengkap 2020: 1/Juknis-100.HK.02.01/III/2020 tentang Pendaftaran Tanah Sistematis Lengkap 2020 adalah suatu kondisi data suatu bidang tanah, dari data spasial dan data yuridis yang disajikan baik dalam bentuk analog maupun digital. Data spasial merupakan data yang menyajikan informasi mengenai letak, batas, luas bidang tanah sedangkan data yuridis merupakan status hukum suatu bidang tanah, pemegang hak, serta beban lain yang membebaninya.

Kualitas data yang buruk akan mengakibatkan terjadinya kesalahan pada saat proses layanan, pengambilan kebijakan, dan ketidakpuasan penerima layanan. Kesalahan saat proses layanan dan pengambilan keputusan mengakibatkan buruknya produk yang dihasilkan, sehingga menimbulkan permasalahan dikemudian hari. Kesalahan tersebut mengakibatkan 
ketidakpuasan penerima layanan terhadap produk yang diterima. Di sisi lain, data yang berkualitas akan menghasilkan informasi pertanahan yang valid dan akurat, serta produk yang berkualitas. Peningkatan kualitas data merupakan penunjang terlaksananya layanan elektronik, serta penopang arah kebijakan atau keputusan. Kualitas data yang baik tentunya akan menghasilkan produk yang berkualitas dan dapat meminimalisir bahkan terhindar dari permasalahan dikemudian hari. Selain itu, saat proses pelayanan berjalan dengan lancar, maka pekerjaan dapat selesai tepat waktu namun tetap menjunjung kualitas dan kuantitas produk yang dihasilkan.

Peningkatan kualitas data dimaksudkan untuk meningkatkan kualitas seluruh data pertanahan menjadi valid baik secara fisik maupun yuridis. Kualitas data dapat ditingkatkan dengan cara menyamakan data fisik dan yuridis pada sistem KKP sehingga memperoleh data pertanahan yang valid. Kantor Pertanahan Kabupaten Klaten terus berusaha untuk meningkatkan kualitas data dengan dilaksanakan validasi data pertanahan. Setelah data informasi pada Komputerisasi Kantor Pertanahan (KKP) sudah valid maka layanan berbasis elektronik dapat dilaksanakan. Bentuk kesiapan data elektronik adalah tervalidasinya data tekstual dan data spasial. Berdasarkan rekapitulasi validasi data pertanahan per-Juli 2021 (www.statistik.atrbpn.go.id), persentase kesiapan data elektronik mencapai 54,48\%. Artinya kesiapan data elektronik masih perlu ditingkatkan dan terus berinovasi agar layanan berbasis elektronik menjadi lebih maksimal dan optimal karena kesiapan data elektronik merupakan ujung tombak terlaksananya layanan elektronik salah satunya Layanan HT-el.

2) Komitmen Pengguna Layanan HT-el (PPAT dan Kreditur)

Komitmen menurut Soekidjan (2009) adalah kemampuan dan kemauan untuk menyelaraskan perilaku pribadi dengan kebutuhan, prioritas dan tujuan organisasi. Hal ini mencakup cara-cara mengembangkan tujuan atau memenuhi kebutuhan organisasi yang intinya mendahulukan misi organisasi dari pada kepentingan pribadi.

Bentuk komitmen adalah tanggung jawab dan memiliki rasa kewajiban terhadap tindakan tertentu, minimal mencakup profesionalisme dan etika dalam bertindak. Apabila pengguna layanan tidak mempunyai komitmen maka akan menghambat proses layanan sehingga membutuhkan waktu dan biaya tambahan karena harus mengulang pekerjaan. Sebagaimana yang diketahui bahwa sertipikat HT-el akan terbit secara otomatis pada hari ke-7 (tujuh) 
terhitung sejak SPS (Surat Perintah Setor) dibayarkan, maka komitmen PPAT dan Kreditor merupakan faktor penting dalam pelaksanaan Layanan HT-el. Selama proses pemeriksaan sampai terbitnya sertipikat HT-el diberikan waktu untuk melakukan perbaikan baik PPAT maupun pihak kreditor. Menurut Juknis HT-el, konsekuensi jika tidak dilakukan perbaikan yaitu ditutupnya berkas dan biaya yang telah dibayar tidak dapat dikembalikan. Oleh karena itu kebenaran data dan kelengkapan serta kejelasan berkas seharusnya menjadi fokus pemohon dalam hal ini PPAT dan pihak Kreditor sehingga dapat meminimalisir kesalahan karena akan berpengaruh pada proses layanan yang sementara berjalan. Selain itu, data dan kelengkapan yang disajikan oleh PPAT dan Kreditor merupakan dasar terbitnya sertipikat HT-el, sehingga baik PPAT maupun kreditor harus memegang komitmen bahwa data dan kelengkapan berkas yang disampaikan kepada Kantor Pertanahan merupakan data yang valid dan dapat dipercaya serta dipertanggungjawabkan.

3) Sosialisasi dan Komunikasi

Manfaat sosialisasi dan komunikasi adalah mempermudah proses layanan dan meminimalisir terjadinya kesalahan. Sosialisasi tentang pengenalan layanan HT-el telah dilaksanakan oleh Kantor Pertanahan Kabupaten yang dihadiri oleh pengguna layanan (PPAT dan Kreditor). Pada saat sosialisasi pengguna layanan praktik secara langsung terkait proses pelayanan HT-el dari tahap awal yaitu pembuatan akun sampai mengunggah dokumen. Sosialisasi yang dilakukan bukan merupakan pembicaraan satu arah saja tetapi dapat dilakukan interaksi antara pihak terkait dalam hal ini Kantor Pertanahan, PPAT dan Kreditur sehingga nantinya pengguna layanan dapat memahami dan melaksanakan pendaftaran HT-el ini dengan sebaik-baiknya Selain itu, kerja sama dan koordinasi yang aktif antara penyedia layanan dan pengguna layanan pada pelaksanaan layanan HT-el di Kantor Pertanahan Kabupaten Klaten. Hal tersebut merupakan kunci utama dalam melaksanakan layanan yang bersifat online sehingga layanan dapat berjalan dengan lancar.

Komunikasi antara Kantor Pertanahan dengan pengguna layanan (PPAT dan Kreditor) tidak hanya dilakukan pada saat awal dimulainya pengenalan HTel saja, tetapi komunikasi tetap dapat terjalin. Kantor Pertanahan Kabupaten Klaten berkomunikasi dengan pengguna layanan melalui Group Whatsapp secara aktif. Komunikasi melalui Group Whatsapp dapat dilakukan untuk menghindari terjadinya kesalahan saat pelaksanaan pendaftaran, dalam proses pemeriksaan 
dan perbaikan bahkan ditutupnya berkas serta dapat menyampaikan kendala atau permasalahan yang terjadi agar dapat terselesaikan dengan cepat dan tepat. Komunikasi ini juga menjadi bagian penting sehingga sertipikat HT-el yang terbit nantinya merupakan sertipikat yang telah melalui proses pemeriksaan serta menjadi produk yang dapat dipertanggungjawabkan.

b. Faktor Penghambat

1) Sarana dan Prasarana

Sarana adalah suatu benda fisik yang tervisualisasi oleh pancaindra baik oleh mata maupun teraba. Prasarana adalah seperangkat alat sebagai penunjang pekerjaan untuk mencapai tujuan. Sarana dan prasarana mempunyai arti yang sama dengan fasilitas yaitu sesuatu yang mendukung dan mempermudah suatu pekerjaan.

Pelaksanaan layanan HT-el yang dilaksanakan oleh Seksi Hubungan Hukum Pertanahan telah disediakan fasilitas yang lengkap terdiri dari 9 (delapan) perangkat komputer, 3 (tiga) buah notebook, 4 (empat) buah server, 1 (satu) buah modem jaringan internet, 4 (empat) buah printer. Jaringan internet pada pelaksanaan layanan khususnya HT-el dituntut untuk stabil terutama saat jam operasional kantor.

Pada dasarnya jaringan internet merupakan salah satu faktor pendukung namun dalam pelaksanaannya jaringan internet saat jam operasional kantor sering mengalami gangguan sehingga untuk menyelesaikan permohonan HT-el membutuhkan waktu cukup lama. Selain itu, gangguan sistem layanan HT-el pada awal pelaksanaan seperti website tidak dapat diakses dan dokumen permohonan tidak dapat diunggah. Hal tersebut dikarenakan sistem layanan HT-el merupakan sistem baru yang masih terus dikembangkan menuju sistem yang sempurna. Waktu yang dibutuhkan cukup lama untuk mempersiapkan dokumen permohonan yang akan diunggah pada sistem karena harus di-scan terlebih dahulu. Dokumen permohonan hasil scan harus dapat terbaca dengan jelas sehingga petugas dapat mengoreksi dengan mudah.

2) Sumber Daya Manusia

Sumber daya manusia (SDM) adalah suatu rancangan dari berbagai sistem formal pada suatu organisasi yang bertujuan memastikan pemanfaatan kemampuan atau keahlian manusia secara efektif dan efisien demi mencapai tujuan organisasi. Pada dasarnya ketersediaan SDM merupakan salah satu faktor pendukung dalam proses Layanan HT-el. Kecukupan SDM belum diimbangi 
dengan kemampuan dalam melaksanakan layanan HT-el. Pelayanan HT-el belum dapat tepat waktu sehingga berdampak pada pemohon atau pengguna layanan. Penanganan solusi yang diharapkan oleh pengguna layanan harus menunggu lama permohonan tertunda dan tentunya akan berpengaruh pada waktu yang dibutuhkan untuk menyelesaikan pekerjaan.

\section{Kesimpulan}

Berdasarkan hasil penelitian dan pembahasan yang telah dikemukakan, maka dapat disimpulkan, pertama, pelaksanaan layanan HT-el berorientasi pada pengguna layanan yang dijelaskan dengan menggunakan 5 (lima) dimensi. Parameter tersebut menjelaskan bahwa efektivitas layanan HT-el di Kantor Pertanahan Kabupaten Klaten memperoleh respon yang baik. Hal ini dibuktikan dengan tanggapan yang baik pada parameter Tangibles (wujud), Reliability (kehandalan), Responsiviness (kecepatan menanggapi), Assurance (jaminan), dan Emphaty (kesediaan memahami). Disiplin waktu pemberian solusi bagi penggunan layanan HT-el masih perlu peningkatan agat terpenuhinya pelayanan prima di Kantor Pertanahan Kabupaten Klaten, sehingga terciptanya kepuasan masyarakat sebagai penerima layanan. Hal tersebut menjadi sumbangsih merubah citra negatif pada layanan Kantor Pertanahan.

Kedua, pelaksanaan Layanan HT-el di Kantor Pertanahan Kabupaten Klaten terdapat faktor pendukung dan faktor penghambat. Faktor pendukung pelaksanaan layanan HT-el di Kantor Pertanahan Kabupaten Klaten adalah meningkatkan kualitas data elektronik, komitmen pengguna Layanan (mitra kerja ATR/BPN) dalam menjamin kebenaran data yang diunggah pada sistem, kegiatan sosialisasi yang berkualitas dan koordinasi antara pengguna layanan dengan petugas layanan. Adapun faktor penghambat pelaksanaan layanan HT-el adalah sarana dan prasarana yang tergolong sudah lengkap namun berfungsi kurang maksimal seperti jaringan internet yang tidak stabil saat jam operasional kantor, gangguan sistem yang mengakibatkan website tidak dapat diakses, proses scan dokumen membutuhkan waktu yang lama karena harus presisi sehingga mudah terbaca. Selain itu, sumber daya manusia (SDM) yang dinilai sudah mencukupi namun terdapat petugas yang kurang menguasai persoalan terkait kendala yang dialami oleh pengguna layanan. Akibatnya pekerjaan tertunda dan tentunya akan berpengaruh pada waktu yang dibutuhkan untuk menyelesaikan pekerjaan. 


\section{Daftar Pustaka}

Amalia, N. V., Qurbani, A. S., \& Kumara, S. (2020). Analisis Ketentuan Hak Tanggungan Elektronik Pada Peraturan Menteri Agraria Dan Tata Ruang Nomor 9 Tahun 2019 Tentang Pelayanan Hak Tanggungan.Jurnal Ilmiah Pendidikan Pancasila dan Kewarganegaraan, 5(2), 332-339.

Andiyanto, K., Mujiburohman, D. A., \& Budhiawan, H. (2021). Penerapan Pendaftaran Hak Tanggungan Terintegrasi Secara Elektronik Di Kantor Pertanahan Kota Pekanbaru. Acta Comitas: Jurnal Hukum Kenotariatan, 6(1), 198-210.

Baswindro, B. (2020). Analisis yuridis pelayanan hak tanggungan terintegrasi secara elektronik (Tesis) Universitas Pelita Harapan.

Exaudia, S., Wahyuni, W., \& Nurasa, A. (2021). Implementasi Pelayanan Hak Tanggungan Terintegrasi Secara Elektronik di Kantor Pertanahan Kota Batam. Marcapada: Jurnal Kebijakan Pertanahan, 1(1), 42-60.

Gunarta, I. M. D., Nurasa, A., \& Pinuji, S. (2020). Persepsi Kreditur dan PPAT Terhadap Kualitas Layanan Hak Tanggungan Terintegrasi Secara Elektronik. Tunas Agraria, 3(3), 75-93.

Kantor Pertanahan Kabupaten Klaten (2020). Laporan Kinerja Kantor Pertanahan Kabupaten Klaten Tahun 2020.

Kantor Pertanahan Kabupaten Klaten. 2021. Rekapitulasi Daftar Baramg Ruangan Kantor Pertanahan Kabupaten Klaten Tahun 2020.

Mardalis. (2013). Metode penelitian suatu pendekatan proposal, Bumi Aksara, Jakarta.

Moleong, L. J. (2010). Metodelogi Penelitian Kualitatif, Remaja Rosda karya, Bandung.

Nadira, N. (2019). Pendaftaran Hak Tanggungan Elektronik Yang Akan Mulai Dilaksanakan Di Badan Pertanahan. Fairness and Justice: Jurnal Ilmiah Ilmu Hukum, 17(2), 162-165.

Soekidjan, S., \& Kj, S. (2009). Komitmen Organisasi Sudahkah Menjadi Bagian Dari Kita. Jakarta: Rineka Cipta.

Suit. (1996). Aspek Sikap Mental Dalam Managemen Sumber Daya manusia. Ghalia Indonesia. Jakarta.

Wiguna, I. W. J. B. (2020). Tinjauan Yuridis Terkait Pendaftaran Hak Tanggungan Secara Elektronik. Jurnal Acta Comitas, 5(1), 79-88. 